\title{
Statyba
}

\section{OPTIMIZATION OF THE POWER AND CONTROL PARAMETERS OF HVAC SYSTEMS IN CONDITION OF THE UNSTEADY DUTIES}

\author{
N. Parfentjeva , O. Samarin \& S. Paulauskaitè
}

To cite this article: N. Parfentjeva, O. Samarin \& S. Paulauskaite (1998) OPTIMIZATION OF THE POWER AND CONTROL PARAMETERS OF HVAC SYSTEMS IN CONDITION OF THE UNSTEADY DUTIES, Statyba, 4:3, 202-205, DOI: 10.1080/13921525.1998.10531405

To link to this article: https://doi.org/10.1080/13921525.1998.10531405

Published online: 26 Jul 2012.

Submit your article to this journal $₫$

Џll Article views: 57 


\title{
OPTIMIZATION OF THE POWER AND CONTROL PARAMETERS OF HVAC SYSTEMS IN CONDITION OF THE UNSTEADY DUTIES
}

\author{
N. Parfentjeva, O. Samarin, S. Paulauskaitė
}

\section{Introduction}

As we know, the main problem faced by the specialists in the HVAC systems is ensuring the required comfort of internal meteorological conditions in the operating zone of rooms with minimal expenses for energy and materials [1]. Therefore, the design of building HVAC systems always assumes certain optimisation of specified engineering decisions. However, this problem becomes very important in our time due to the substantial increase of requirements for economical efficiency of the HVAC systems and the maintenance of given parameters of indoor air in variable external and internal exposures $[2,3]$. It results in a need for new approaches to calculations, design, the operation of HVAC systems and their automatic control systems (ACS).

\section{Method and results of investigations}

One of the most promising techniques which allows to achieve a substantial decrease in the maximal capacity of HVAC systems (in comparison with traditional methods) is a joint consideration of transients possible to use their own thermostability of rooms, partially (and sometimes fully) to maintain a given thermal condition by the correlation of unit-step responses of the shown objects which are, in essence, the unified systems. In this case, it is possible to decrease the design-basis capacity of HVAC systems and to simplify the controllers using a lead of heat disturbances by action of HVAC systems controlled by ACS with PD or even P-control algorithm. Simultaneously, it becomes expedient to pass the maintenance function of the daily average internal air temperature $t_{a}$ to the qualitative control of central heat (cold) supply. Then the local ACS will only compensate the difference between the set-point temperature and $t_{a}$, and the proposed procedure of optimising the capacity of HVAC systems. And control parameters are developed just for such conditions.

The given procedure is based on an assumption that common thermostability $P_{\text {com }}$ of the system «room-HVAC and ACS-systems» combines room admittance $P_{\text {room }}$ and a control action of ACS $K_{c}$ [4].

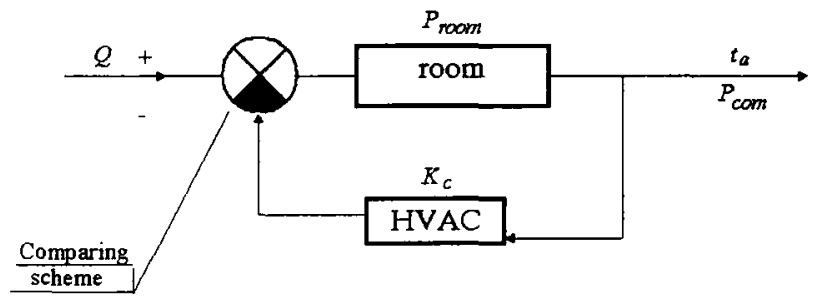

Fig 1. The automatic control circuit of the indoor microclimate

This immediately follows from the opposingparallel connection of units corresponding to a room and HVAC systems in the circuit of automatic control of the indoor microclimate (Fig 1). Therefore HVAC system will compensate only that part of heat disturbance $Q$, which cannot be balanced due to internal damping in the system. It is possible to show that this part can be expressed by amplitude of disturbance $A_{q}$ and the generalised coefficient of assimilation of variable excess heat $K_{\text {ass }}$. The latter is a further development of the concept of assimilation coefficient, which was first introduced [5] with reference to the compensation of radiant disturbances by convective 
actions of HVAC systems but without reference to the automatic control of them. Then, the installation power of HVAC systems $Q_{\text {ins }}$ combines the compensated part of disturbance and the average duty over the period $Q_{a v}$ :

$$
Q_{i n s}=Q_{a v}+K_{a s s} \cdot A_{q} .
$$

In the most general case, the assimilation coefficient depends on the requirements to maintain the indoor temperature, ie on its acceptable amplitude $A_{t a}$, the thermostability of a room, the amplitude of heat disturbance $q_{r}$ and compensating action of HVAC systems $q_{r, h v a c}$ :

$$
K_{\text {ass }}=A \cdot\left(1-B \cdot R_{d}\right) \cdot B_{0} \text {, }
$$

where $R_{d}=A_{t a} \cdot \frac{P_{r o o m}}{A_{q}}$ is the dynamic control coefficient of HVAC systems $B_{0}=f \cdot\left(q_{r 1} \cdot q_{r, h v a c}\right)$ is the measure of assimilation of radiant heat disturbances. $\mathrm{A}$ and $\mathrm{B}$ are parameters characterising the control algorithm. To some extent the form of specified control algorithm also affects $K_{\text {ass }}$ (because of its influence on values of $\mathrm{A}$ and $\mathrm{B}$ ), and it is possible to show that the maximal effect from, the specified, like this measures take place using proportional and derivative controllers with PD-control algorithm with specially fitted derivation period $T_{d}$. The latter depends mainly on averaged head inertia of room $D_{a \nu}=\frac{\Sigma D F}{\Sigma F}$ and allows to compensate the time lag of room response to heat disturbance:

$$
T_{d}=1,17 \cdot\left(3,5-D_{a v}\right), h r s
$$

but not less than 1,17 and not more than 2,93 hours at 24-hours period of variations of heat disturbance. In this case $\mathrm{A}=\mathrm{B}=1$, and $K_{\text {ass }}$ takes a minimally possible value for the given system which is equal to $\left(1-R_{d}\right) \cdot B_{0}$. Nevertheless, using a simpler and routine $\mathrm{P}$-algorithm it is possible to achieve results, rather closely spaced to the optimal ones (especially when HVAC system is the heating one). The parameters A and $B$ in this case differ from 1 : $A$ increases (maximal magnitude is equal to 1,25 ), and $B$ decreases up to 0,9 0,95 .
By definition, assimilation coefficient is always less than 1 , the thermostability of a room is never equal to zero. It is assumed, however, that the radiant fraction in heat emission (assimilation) of HVAC system $Q_{H V A C}$ does not exceed the corresponding fraction in heat disturbance, so the condition $\hat{A}_{0}<1$ is satisfied conforming to the known point [5] that it is more preferable to use a convective way of compensation of radiant heat excess. In the specific case, when the resources of a room are sufficient for maintaining the designed internal conditions within required limits that takes place when $R_{d} \geq 1$, assimilation coefficient is equal to zero, and the automatic control by deviation from the average value is not required. Otherwise, the gain $K_{1}\left[\frac{W t}{K}\right]$ of proportional term of the controller should be determined. This gain is related to the assimilation coefficient and provides, with the specified value of $T_{d}$, the required control action of ACS:

$$
K_{1}=C \cdot K_{a s s} \cdot \frac{A_{q}}{A_{t a}}
$$

where $C$ is a parameter characterising control algorithm. When using proportional algorithm realised by P-controllers, $C=1$; when using the optimal PDalgorithm, $C$ decreases, and the least magnitude takes place for rooms with predominantly «light» enclosure and is equal to 0,75 .

Certain original ideas, being concerned with the described approach to calculation of the power of HVAC systems, were advanced earlier [6], but here they are used in a somewhat different form and interpretation. We should specially emphasize that the problem determining the minimally necessary HVAC power proves to be correlated with the calculation of heat inertia of a room and the unit-step responded of specified ACS. In this case obtaining savings is complex in character so far, as it is reduced not only to decrease of overall dimensions of the equipment but also to shortening the flow rate of the hot (cold) fluids (including the air flow) as well as the diameters of pipelines and air ducts and energy expenditures to move the fluids in the pipelines. Moreover, there is an increase in the coefficient use of installation equipment power because of shortening the gap between 
maximal and average duty of HVAC systems. In essence, for an advanced optimisation of HVAC systems it is feasible a more complete way for using passive (structural and volume-layout) HVAC elements for maintenance of the required parameters of indoor atmosphere and so the decrease role is active. HVAC terms, and hence an opportunity of energy saving (in comparison with traditional approaches).

It is possible to determine the dimensions of the achieved saving in the given case on the basis of the following characteristic example. Calculations have been carried out for the room with a floor area of $16 \mathrm{~m}^{2}$ with maximal heat excess $Q_{\max }=1500 \cdot \mathrm{Wt}$, so that $A_{q}$ is also equal to $750 \cdot W t$. It was 9 hrsduration $Q_{a v}=750 \cdot W t$, so that $A_{q}$ is also equal to $750 \mathrm{Wt}$. It was assumed, that the increase of excess heat was connected predominantly with solar radiation, thus the radiant fraction in them $q_{r}=0,8$. The other $20 \%$ reach by convection window surfaces. As HAC system the air convective cooling system was specified, ie $q_{r, \text { hvac }}=0$. Characteristics of the enclosure correspond to a regular room in a building with silicate brick walls, gypsum-concrete bulkheads and hollow reinforced concrete ceilings. In this case the thermostability of the room $P_{\text {room }}=460 \cdot \frac{W t}{K}$, when the floor height is equal to $2,7 \mathrm{~m}$, and value $B_{0}=0,57$.

Then using P-control algorithm for HVAC systems and rather stringent requirements to the amplitude of the indoor temperature (equal to $1^{\circ} \mathrm{C}$ ), the sufficient installation power of the equipment $Q_{\text {ins }}=940 \cdot W t$ that corresponds to the magnitude $K_{\text {ass }}=0,25$. It takes only $63 \%$ of the maximal duty of the room and $16 \%$ less than the magnitude found from existing procedure of calculation in the unsteady thermal regime of a room [5] with no regard to the effect of automatic control upon the power of HVAC systems and equating in essence, the coefficient $K_{\text {ass }}$ to the value $B_{0}$. When using the optimal PD-control algorithm, the required power decreases up to $915 \cdot \mathrm{Wt}$, and the difference increases up to $39 \%$ and $19 \%$ correspondingly, that can be provided using the parameters of ACS $K_{1}=190 \cdot \frac{W t}{K}$ and $T_{d}=2,9 \mathrm{hrs}$.
The pattern of transient processes in the system "room-HVAC and ACS-systems» is shown in Fig 2. When extending the feasible range of variation of indoor temperature up to $1,65 \mathrm{deg}$. to both directions from the average one, the installation power acquires the minimally feasible magnitude which is equal to $Q_{a v}(940 \cdot W t)$.

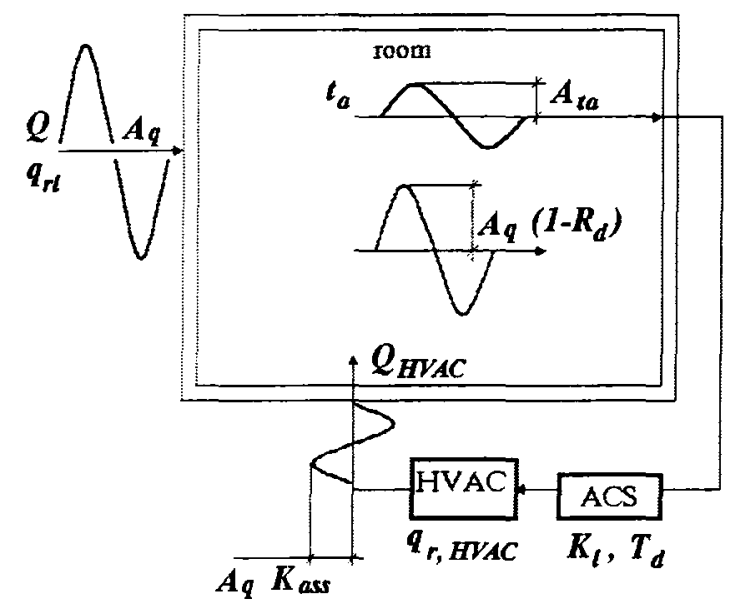

Fig 2. The pattern of transient processes in the system "room-HVAC and ACS-systems» in condition of the unsteady duties

It is necessary that all the shown reasoning hold true in any behaviour of the heat exposure variations (not only in the regular ones). Under unit-step disturbances the count of amplitudes shall be performed not from the average magnitudes but from the reference ones (before disturbance). Besides, the thermostability of the room cannot be calculated by traditional procedures, because it proves to be variable. The corresponding measure can be defined using data [7] depending on the specified duration of a setting time.

\section{Conclusions}

The given procedure of the optimisation of the HVAC power and ACS parameters to a sufficient extent takes into account the main factors effecting the unsteady thermal conditions of room. It is a simple and convenient way for engineers and it fully corresponds to the concept of creation of Buildings with Efficient Use of Energy [2]. Besides, it is suitable for comparing alternative schemes of the basic HVAC decisions even in the producing survey stage, and that causes its main usefulness in practice. 


\section{References}

1. В.П. Титов. Учет нестационарных тепловых процессов в помещении // Водоснабжение и санитарная техника, 1994, № 3, с. $11-13$.

2. В.Н. Богословский. Три аспекта концепции ЗЭИЭ и особенности переходного периода // Сб. докл. конф. НИИСФ, 1997, Т. 1, с. 7 - 9 .

3. Ю.А. Табунщиков. Расчеты температурного режима помешения и требуемой мощности для его отопления или охлаждения. М.: Стройздат, 1981. 84 с.

4. О.Д. Самарин. Расчет нестационарного теплового режима помещения в условиях автоматического регулирования систем кондиционирования микроклимата // Сб. докл. конф. НИИСФ, 1997, Т.1, c. $67-71$.

5. Е.Г. Малявина. Учет аккумулирующей способности помещений при определении тепловой нагрузки на систему кондиционирования воздуха // Проектирование отопительно-вентиляционных систем, ЦНИИС. Реф. сб., № 2, М., 1973, с. 63-72.

6. Ю.Я. Кувшинов. Энергосбережение при кондиционировании микроклимата гражданских зданий. Автореф. дис. ... д-ра техн. н. М., МИСИ, 1989. $24 \mathrm{c}$.

7. О.Д. Самарин. О рациональном режиме начального прогрева помешения // Известия вузов. Строительство, 1997 , № 3 , с. $83-85$.

Iteikta 19980619

\section{ŠILDYMO, VĖDINIMO IR ORO KONDICIONAVIMO SISTEMU GALIOS IR VALDYMO PARAMETRU OPTIMIZAVIMAS NESTACIONARAUS REŽIMO SALYGOMIS}

\section{N. Parfentjeva, O. Samarin, S. Paulauskaitè}

\section{Santrauka}

Kaip žinia, pagrindinis šildymo, vèdinimo ir oro kondicionavimo sistemu - mikroklimato kondicionavimo sistemų (MKS) - specialistų uždavinys yra reikiamų mikroklimato parametrų užtikrinimas patalpos darbo zonoje minimaliomis materialinemis ir energetinèmis sąnaudomis. Ypač svarbi ši problema kylant MKS ekonomiškumo ir nustatytu aplinkos parametrų užtikrinimo reikalavimams esant kintamiems vidiniams ir išoriniams poveikiams. Tai reikalauja naujo požiūrio i MKS sistemų skaičiavimą, projektavimą, eksploatavimą ir automatinị reguliavimą.
Siekiant sumažinti maksimalią MKS galią perspektyvu kompleksiškai nagrineti dinaminius procesus, vykstančius patalpoje, mikroklimato kondicionavimo sistemoje ir automatinio reguliavimo sistemoje (ARS). Be to, siejant minèty objektų dinamines charaktristikas i vieningą sistemą reguliaraus režimo sąlygomis pasirinktai tempetatūrinei aplinkai palaikyti, iš dalies galima išnaudoti patalpos savaji šilumini pastovumą.

Pasiūlyta metodika, kurioje daroma prielaida, kad bendras sistemos "patalpa - MKS - ARS" šiluminis pastovumas susideda iš patalpos šiluminio pastovumo rodiklio ir ARS valdančio poveikio, del ko MKS turi kompensuoti tik dali šilumos poveikių patalpoje. Ši dalis išreiškiama poveikiu amplitude ir apibendrintu kintančiu šilumos išsiskyrimų koeficientu.

Pateikta MKS galios ir ARS parametry optimizavimo metodika, ịvertinanti pagrindinius faktorius, darančius įtaka nestacionariam patalpos šilumos režimui, yra pakankamai paprasta. Ji gali būti taikoma principiniams MKS sprendimams palyginti.

Natalja PARFENTJEVA. Doctor, Professor. Department of General Physics. Moscow State Building University, Moscow, 129337, Jaroslavskoje 26.

Author of about 150 published research works and study guides. Research interests: non-static heat and mass transference in non-linear physical medium, in combustion and phase change, in polylayers and polyphase systems.

Oleg SAMARIN. Engineer, PhD student and Assistent. Department of Heating and Ventilation. Moscow State Building University, Moscow, 129337, Jaroslavskoje 26.

Author of 9 published research works and study guides. Research interests: dynamics of microclimate conditioning systems and its automatic regulation as well as its connection with heat stability in premises.

Sabina PAULAUSKaITÉ. Doctor, Associated Professor. Department of Heating and Ventilation. Vilnius Gediminas Technical University. Sauletekio al. 11, 2040 Vilnius, Lithuania.

Research visits to: Civil Engineering Institute of Moscow (1976), Horsens Polytechnic (Denmark, 1994-1995). Author of about 40 scientific articles. Research interests: renovation of buildings and heating systems, energy saving in buildings. 